\title{
CS-21 - La función de los organismos públicos de derechos humanos en la protección del derecho a la vivienda adecuada en México
}

\section{The role of national human right institutions in the protection of the right to adequate housing in México}

\author{
José A. Del Rivero
}

División Académica de Ciencias Sociales y Humanidades, Universidad Juárez Autónoma de Tabasco, México

Autor a quien se dirige la correspondencia: josealberto@delriveroasociados.mx

\section{Resumen}

$\mathrm{Z}^{1}$ presente documento analiza el cumplimiento de las obligaciones de promover, respetar, proteger y garantizar el - derecho a la vivienda adecuada por parte de las autoridades de los organismos públicos de protección de derechos humanos. Para lograr este propósito, el punto de partida de estetrabajo es la interpretación de los artículos 1o. y 4o. de la Constitución Política de los Estados Unidos Mexicanos y el análisis de las disposiciones que integran el bloque de constitucionalidad aplicable a la materia y que son fuente de un amplio catálogo de obligaciones y deberes para las autoridades estatales, así como de diversos instrumentos y procedimientos para proteger los derechos humanos. Los resultados de esta investigación destacan la inexistencia de un procedimiento ex profeso para la justiciabilidad del derecho a la vivienda adecuada en México, por lo tanto, cuando se cometen hechos que constituyen violaciones a este derecho, se acude a los procedimientos no jurisdiccionales que están a cargo de las Comisiones Nacional y Estatal de Derechos Humanos. En esta investigación se advierten algunas omisiones en el respeto, protección y promoción del derecho a la vivienda adecuada, que cuestionan la eficacia de los mecanismos y procedimientos que se realizan en dichas instituciones. Finalmente, se infiere que los organismos públicos de derechos humanos son ineficaces para garantizar el pleno cumplimiento y la justiciabilidad del derecho a la vivienda adecuada en México.

Palabras claves: Derecho a una vivienda adecuada, obligaciones generales del Estado, mecanismos de protección de derechos humanos, organismos públicos de derechos humanos, violaciones al derecho a la vivienda

\section{Abstract}

$\mathrm{T}$ his paper analyzes the fulfillment of the obligations to promote, respect, protect and guarantee the right to adequate housing by the authorities of public agencies for the protection of human rights. This researchhas as reference the interpretationof articles 1 and 4 of the Political Constitution of the United Mexican States and the analysis of the provisions that make up the block of constitutionality applicable to the matter and which are a source of a broad catalog of obligations and duties for state authorities, as well as some instruments and procedures to protect human rights. The results of this research highlight the lack of an ex profeso procedure for the justiciability of the right to adequate housing in Mexico, therefore, when facts are committed that constitute violations of this right, we refer to non-jurisdictional procedures that are charge of National Human Rights Institutions. This research reveals some omissions in respect, protection and promotion of the right to adequate housing, which question the effectiveness of the mechanisms and procedures carried out in these institutions. Finally, it is inferred that public human rights bodies are ineffective in ensuring full compliance and justiciability of the right to adequate housing in Mexico.

Key words: The right to adequate housing, general obligations of States, mechanisms for the protection of Human Rights, National Human Rights institutions, violation of the right to adequate housing 